\title{
Effect of Visual Merchandising on Apparel Impulse Buying Behaviors among Iranian Young Adult Females
}

\author{
Meysam Moayery ${ }^{1 *}$, Samar Zamani ${ }^{2}$ and Hosein Vazifehdoost ${ }^{3}$ \\ 'Department of Textile Engineering, Science and Research Branch, Islamic Azad University, Tehran, \\ Iran; meysam.moayery@gmail.com \\ 2Department of Business management, Abhar Branch, Islamic Azad University, \\ Abhar, Iran; Samar_zamani@yahoo.com \\ ${ }^{3}$ Department of Executive Management, Science and Research Branch, Islamic Azad University, \\ Tehran, Iran; vazifehdust@yahoo.com
}

\begin{abstract}
The purpose of this paper is to investigate the relation between apparel impulse buying behavior and visual merchandising among Iranian young adult females. For this purpose a sample of 150 young adult females in Iran complete the questionnaire which contained measures of impulse buying, window display, in store form/mannequin display, floor merchandising, promotional signage, cross merchandising design. The outline for analysis is as follows: first, descriptive statistic and frequency table. Then Kolmogorov-Smirnov test, principal component analysis with reliability test, Pearson correlation test. Finally, multiple linear regression analysis for hypotheses testing and BETA analysis to illustrate the greater effect on impulse buying. The results of the present study prove that there is a pivotal relation between Iranian young adult females' impulse buying behavior and three types of visual merchandising practices: window display, in store form/mannequin and promotional signage. The findings are useful for retailers to perceive the nature of impulse buying behavior and factors, such as visual merchandising, which can influence consumer's impulse buying behaviors.
\end{abstract}

Keywords: Consumer Behavior, Impulse Buying Behavior, Visual Merchandising

\section{Introduction}

It is claimed that four out of five percent of all purchases in special product categories is allocated to impulse buying in USA and it makes up $\$ 4$ billion annually ${ }^{1}$. We are cognizant of the importance of developing and effective strategy because completion in retail sector have been increasing during last years ${ }^{2}$. Previous research in Iran proved that women are more engaged in apparel impulse buying than men $^{3}$. In addition, other researches in Iran showed that merchandising can influence consumer's buying behavior ${ }^{4}$. In a research by $\mathrm{Kim}^{10}$, it is proved that in store display and promotional signage can influence college's apparel impulse buying behavior ${ }^{10}$. As mentioned, although researches in Iran have investigated the impulse buying behavior and merchandising separately, they have never investigated the relation between apparel

${ }^{*}$ Author for correspondence impulse buying behavior and visual merchandising and how visual merchandising might increase apparel impulse buying in consumer. Therefore, the purpose of our study was to identify the factors which might influence Iranian young adult females' apparel impulse buying behavior and to complete previous research such as Kim's research which investigated four items of visual merchandising.

\section{Literature Review}

\subsection{Importance of Consumer Behavior in Marketing}

Hoyer et al. suggest that consumer buying behavior study involves understanding whether, why, when, where, how, how much, how often and how long consumers will buy ${ }^{6}$. It is crucial for marketer to have the ability of controlling 
the behavior of consumer, but they do not have enough power and information to do that ${ }^{7}$. Some researches in Iran indicate that factors including promotional activity and visual merchandising can provoke impulse buying behavior $^{8}$, which can reveal the importance of consumer buying behavior in marketing.

\subsection{Impulse Buying}

Impulsive purchases occur whenever customers experience an unexpected incentive to buy something without delay, without extra evaluation and act based on the urge ${ }^{9}$. Impulse buying makes up a subject of great profitability for marketers ${ }^{10}$. It is proved that consumer behaviors are influenced by internal and external stimuli ${ }^{5}$. Internal factors refer to such internal states and characteristics of individuals including person's emotional state, mood and self-feelings ${ }^{8}$. External or environmental cues embrace atmospheric cues in shopping environment and marketing mix stimuli ${ }^{5}$. Previous researches have proved that factors like in-store form display, visual merchandising, promotional and economic effect (coupons and cheaper prices) can encourage people to buy without any pre-shopping intention ${ }^{5,8,11}$. A research in Iran showed that Iranian shoppers give attention to visual communication and visual merchandising. According to Muruganantham and Bhakat ${ }^{12}$ "impulse buying is an action undertaken without previously having been consciously recognized or a buying intention formed prior to entering the store". This phenomenon is defined as more stimulating, less planed, and more on ineluctable buying behavior compared to the intended purchasing behavior ${ }^{13}$.

\subsection{Visual Merchandising}

In order to show merchandise and concept in their very best we use visual merchandising or display with the final purpose of making a sale ${ }^{14}$. Visual merchandising encompasses from display, floor/wall merchandising and promotional signage ${ }^{5}$. Also it is suggested that cross merchandising can increase sale in apparel retailers ${ }^{1}$. We define cross merchandising as merchandising product from different categories together. It can offer to customers items that they overlook ${ }^{15}$. We can identify an organized store from three criteria:1-an ambience that is conducive for shopping 2-providing goods and services that appeal to consumers 3-professionally managed large format stores $^{2}$. The different stimulant inside store can influence the customer directly or indirectly. Lighting, layout, presentation of merchandise, fixtures, floor coverings, colors, sounds, odors, and dress and behavior of sales and service personnel can influence store's atmosphere. Interesting and nice store environment will result in enhanced impulse buying ${ }^{12}$. Based on the review of literature the following hypotheses were developed (see Figure 1):

H1. Iranian young adult females who purchase on impulse are influenced by widow display.

H2. Iranian young adult females who purchase on impulse are influenced by in sore form/mannequin display.

H3. Iranian young adult females who purchase on impulse are influenced by floor merchandising.

H4. Iranian young adult females who purchase on impulse are influenced by promotion signage.

H5. Iranian young adult females who purchase on impulse are influenced by cross merchandising.

\section{Methodology}

\subsection{Instrument}

To begin, the used instrument for this study was in survey format. The questionnaire includes of seven major sections measuring consumer impulse buying tendency, influence of visual merchandising and demographics. The first section of survey measured consumer's impulse buying tendency. Section two through the section six consisted of practices that were supposed to impact consumer's buying tendency. These were window display, in store form/mannequin display, floor merchandising, promotional signage, and cross merchandising. Lastly, the final section consisted of questions to determine the

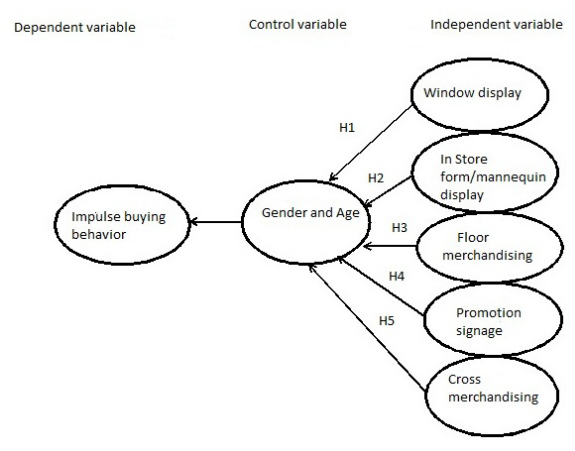

Figure 1. Propsed model. 
respondent's demographic profile including income, and age. A five point LIKERT scale, ranging from never=1 to frequently $=5$ was used to measure each variable.

\subsection{Measures}

Previous researches implied that there are three criteria for unplanned purchase: response to in store stimuli, no previously recognized problem and rapidity of purchase decision. As a result, questions in the first section regarded consumer's impulse buying tendency in respect to these criteria. In the Second section,we lodged questions concerning consumer impulse buying behavior influenced by window display to see if window display influenced respondents to enter a certain store or to make a purchase decision. The third section embraced question concerning consumer impulse buying behavior influenced by in store form/mannequin display when he or she made a purchase decision.

In addition, the fourth section is designed to understand whether consumer impulse buying behavior influenced by floor merchandising when the participant made a purchase decision. A plethora of retailers are using a floor merchandising Plano-O-Gram/Zone-O-Gram in relation to grab the customer attention when pass by. Questions in relation to finding out the influence of promotional signage on consumer impulse buying behavior were come in the fifth section ${ }^{5}$. The sixth section that is developed by researcher, included question regarding consumer's impulse buying behavior influenced by cross merchandising. From first section to sixth, the questions extracted from Kim's questionnaire ${ }^{5}$ and the sixth section was developed by researcher. Important factors on cross merchandising were identified from literature then questions were developed according on this factors. Next, validity of the sixth section was evaluated by experts and reliability was measured by Cronbach alpha method. In addition, this questionnaire provide as a reliable instrument with Cronbach's $\alpha=0.84$ for the complete 21 items. The last section included demographic questions including age, and income.

\subsection{Sample}

As mentioned in introduction, a research in Iran proved that women are more engaged in apparel impulse buying than men $^{3}$. Samples of that research were women between 17 to 35 years in Tehran. As a result, in this project researcher selected women between 17 to 35 in
Tehran that were buying apparel in one of the famous apparel store in Tehran (Tandis Co). Data were collected from convenient sample and a total of 150 of the 200 survey questionnaires administered were complete. Slightly lower than half of the respondents (48 percent) were ages 21 to 25 years old. Approximately 40 percent reported a monthly income/allowance of more than 6,000,000 Rials (equivalent to 30 USD).

\subsection{Data Analysis Method}

Prior to survey distribution, a statistician was consulted to ensure the questions would be applicable and also to determine the most suitable statistics to use for this research. The plan for analysis is as follows: first, descriptive statistics and frequency tables will be generated by SPSS for a data entry error check and demographic analysis. Then, Kolmogorov-Smirnov test will be able to prove the accuracy of using parametric statistics. Next, principle component analysis with reliability test will be conducted. The Pearson correlation tests will be conducted to see the correlation between consumer's impulse buying behavior and each of five types of visual merchandising practices. Prior to conducting the multiple regression analysis, regression assumptions were tested. Finally, regression analysis will be conducted for hypotheses testing to find out the relation between consumer impulse buying tendency (dependent variable) and the five type of visual merchandising (independent variable). The descriptive statistics for each variable is shown in Table 1.

In the questionnaire different items including three to five items were developed to measure each variable under study. We apply Principal component analyses with Varimax rotation to reduce these measures into single variables. Furthermore internal consistency was checked using Cronbach's alpha to ensure the reliability of data reduction. Table 2 reveals that all of items have a factor loading of 0.5 or greater which shows each item belongs to only one group.

\section{Hypothesis Testing}

H1. Iranian young adult females who purchase on impulse are influenced by window display. Based on Pearson correlation test (Table 3) a significant correlation was shown between impulse buying and window display with a $\mathrm{p}$-value less than $0.05(\mathrm{p}<0.005)(\mathrm{r}=0.383)$.In addition the regression analysis found that window display 
Table 1. Descriptive Statistics for Variables

\begin{tabular}{lccc}
\hline Variables & Number of Cases & Mean & Standard Deviation \\
\hline Impulse Buying Tendency & 150 & 3.0450 & 0.83398 \\
Influence of Window Display & 150 & 3.0289 & 1.07367 \\
Influence of Form/Mannequin Display & 150 & 2.9850 & 0.92106 \\
Influence of Floor Merchandising & 150 & 3.5244 & 0.95331 \\
Influence of Promotional Signage & 150 & 3.2567 & 1.07322 \\
Influence of Cross Merchandising & 150 & 2.9267 & 1.12252 \\
\hline Scale values: Never=1 to frequently=5 & & &
\end{tabular}

Table 2. Factor Analysis Results

\begin{tabular}{|c|c|c|c|c|c|}
\hline Factor & Item & Factor Loading & Eigenvalue & $\%$ of Variance & Alpha Coefficient \\
\hline \multirow{5}{*}{$\begin{array}{l}\text { Impulse Buing } \\
\text { Tendency }\end{array}$} & Question 1 & 0.594 & \multirow{5}{*}{1.618} & \multirow{5}{*}{40.42} & \multirow{5}{*}{0.6011} \\
\hline & Question 2 & 0.534 & & & \\
\hline & Question 3 & 0.693 & & & \\
\hline & Question 4 & 0.707 & & & \\
\hline & Question 5 & 0.818 & & & \\
\hline \multirow{4}{*}{$\begin{array}{l}\text { Influence of } \\
\text { Window Display }\end{array}$} & Question 6 & 0.740 & \multirow{4}{*}{1.943} & \multirow{4}{*}{64.768} & \multirow{4}{*}{0.7242} \\
\hline & & & & & \\
\hline & Question 7 & 0.852 & & & \\
\hline & Question 8 & 0.679 & & & \\
\hline \multirow{4}{*}{$\begin{array}{l}\text { Influence of } \\
\text { Form/Mannequin } \\
\text { Display }\end{array}$} & Question 9 & 0.748 & \multirow{4}{*}{2.224} & \multirow{4}{*}{55.606} & \multirow{4}{*}{0.7280} \\
\hline & Question 10 & 0.714 & & & \\
\hline & Question 11 & 0.833 & & & \\
\hline & Question 12 & 0.533 & & & \\
\hline \multirow{4}{*}{$\begin{array}{l}\text { Influence of Floor } \\
\text { Merchandising }\end{array}$} & Question 13 & 0.781 & \multirow{4}{*}{1.570} & \multirow{4}{*}{52.314} & \multirow{4}{*}{0.5061} \\
\hline & & & & & \\
\hline & Question 14 & 0.878 & & & \\
\hline & Question 15 & 0.886 & & & \\
\hline \multirow{4}{*}{$\begin{array}{l}\text { Influence of } \\
\text { Promotional } \\
\text { Signage }\end{array}$} & Question 16 & 0.826 & \multirow{4}{*}{2.717} & \multirow{4}{*}{67.921} & \multirow{4}{*}{0.8392} \\
\hline & Question 17 & 0.834 & & & \\
\hline & Question 18 & 0.744 & & & \\
\hline & Question 19 & 0.828 & & & \\
\hline \multirow{3}{*}{$\begin{array}{l}\text { Influence of Cross } \\
\text { Merchandising }\end{array}$} & Question 20 & 0.889 & \multirow{3}{*}{2.139} & \multirow{3}{*}{71.313} & \multirow{3}{*}{0.7971} \\
\hline & & & & & \\
\hline & Question 21 & 0.814 & & & \\
\hline
\end{tabular}


significantly influenced consumer's impulse buying behavior. $\mathrm{p}$-value $(\mathrm{p}<0.005)$ smaller than alpha level, supporting the researcher's hypothesis (see Table 4).

H2. Iranian young adult females who purchase on impulse are influenced by in store form/mannequin display. Pearson correlation test with a small $\mathrm{p}$-value $(\mathrm{p}<0.005) \quad(\mathrm{r}=0.405)$ confirm a significant correlation (Table 3). Also, the regression analysis showed that form/ mannequin display effected consumer's impulse buying behavior. Moreover, the $\mathrm{p}$-value $(\mathrm{p}<0.005)$ was smaller than alpha level, supporting the researcher's hypothesis.

H3. Iranian young adult females who purchase on impulse are influenced by widow display. There is Significant correlation between impulse buying and in store form/mannequin display which was proved (Table 3 ) by Pearson correlation test $(\mathrm{r}=0.252)(\mathrm{p}<0.005)$. Although, the Pearson correlation test showed a significant relation between impulse buying and floor merchandising, the regression analysis suggest that the floor merchandising did not significantly influence consumer impulse buying behavior ( $\mathrm{p}>0.005)$.

H4. Iranian young adult females who purchase on impulse are influenced by promotional signage. A Pearson correlation test found a significant correlation between impulse buying and promotional signage with a p-value less than $(\mathrm{p}<0.005)(\mathrm{r}=0.372)$. So, it is suggested that promotional signage was significantly related with consume impulse buying behavior. Furthermore, the regression analysis found that promotional signage significantly influence consumer impulse buying behavior. The $\mathrm{p}$-value $(\mathrm{p}<0.005)$ was smaller than alpha level, illustrated that the data provided sufficient evidence that there was a significant directional relationship between consumer's impulse buying behavior and promotional signage.

H5. Iranian young adult females who purchase on impulse are influenced by cross merchandising. The result of a Pearson correlation test found a significant correlation between impulse buying and cross merchandising.

Table 3. Correlation with Impulse Buying

\begin{tabular}{lcc}
\hline Variables & Coefficient $(\mathrm{r})$ & Significance $(\mathrm{p})$ \\
\hline Window Display & 0.383 & 0.000 \\
Form/mannequin Display & 0.405 & 0.000 \\
Floor Merchandising & 0.252 & 0.002 \\
Promotional Signage & 0.372 & 0.000 \\
Cross merchandising & 0.280 & 0.001 \\
\hline
\end{tabular}

However, even though the Pearson correlation test showed a significant relationship between impulse buying and cross merchandising, the regression analysis suggested that the floor merchandising did not significantly influence consumer's impulse buying behavior. Therefore the final equation is as following:

Impulse Buying $=1.166+(0.180 \times$ window display $)+$ $(0.171 \times$ in store mannequi)

In addition, to understand this question that which of the dependent variable have a greater effect on impulse buying we can use beta coefficient ${ }^{16}$. The beta result shows that the window display contributed the most in explaining the apparel impulse buying behavior, followed by the promotional signage, and then the in-store form/ mannequin (BETA $=0.231,0.220,0.189$ respectively) (see Figure 2).

\section{Conclusions and Implications}

This study investigated a structural model that examined the relationships among visual merchandising factors and apparel impulse buying behavior of 150 young adult female in Iran. It provides insights to shops owner and researchers for understanding structural relationships between visual merchandising and apparel impulse buying behavior. The results propose that Window display, in store form/mannequin display and promotional signage directly affect apparel impulse buying. Although cross merchandising and floor merchandising did not appear to significantly lead consumer's impulse buying behavior, the results still suggested that these variables and consumers' impulse buying behavior are significantly correlated. Retailers should pay attention to visual merchandising

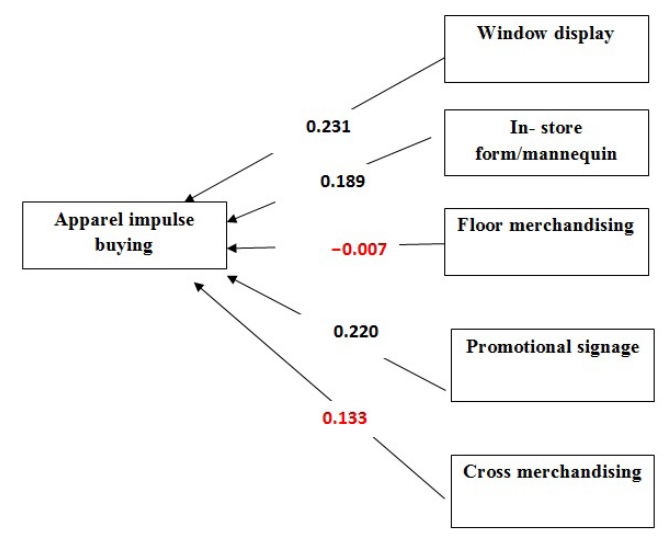

Figure 2. Variables Related to the apparel impulse buying behavior. 
Table 4. Final result of regression analysis

\begin{tabular}{lcccc}
\hline Hypothesis & B & P-value & $\beta$ & T-statistics \\
\hline $\begin{array}{l}\text { H1.Consumer who purchase on impulse are } \\
\text { influenced by window display }\end{array}$ & 0.180 & 0.004 & 0.231 & 2.954 \\
$\begin{array}{l}\text { H2.Consumer who purchase on impulse are } \\
\text { influenced by in store form/mannequin display }\end{array}$ & 0.171 & 0.029 & 0.189 & 2.207 \\
$\begin{array}{l}\text { H3.Consumer who purchase on impulse are } \\
\text { influenced by floor merchandising }\end{array}$ & -0.006 & 0.932 & -0.007 & -0.085 \\
$\begin{array}{l}\text { H4.Consumerwho purchase on impulse are } \\
\text { influenced by promotional signage. }\end{array}$ & 0.171 & 0.007 & 0.220 & 2.748 \\
$\begin{array}{l}\text { H5.Consumer who purchase on impulse are } \\
\text { influenced by cross merchandising. }\end{array}$ & 0.099 & 0.079 & 0.133 & 1.772 \\
\hline
\end{tabular}

practice since this can trigger impulse buying of apparel. When consumers are exposed to these visual stimuli, they are more likely to make a purchase decisions on impulse ${ }^{5}$. This propose that these visual merchandising factors, serving as motive that arouse a desire which ultimately persuades a consumer to make a spontaneous purchase decision upon entering the store, considerably impress consumers' impulse buying behaviors.

The results of one study by Mattila and Wirtz proved that high stimulating and pleasant store environment will result in increased impulse buying. Furthermore, when the store environment was perceived as over stimulating, the highest self -reported impulse buying was recorded ${ }^{17}$. The result of present study provided adequate evidence that shop owners can apply visual merchandising to soar desirability of products and to help customers being cognizant of the products as well as to make favorable attitudes. Furthermore, this study created new insights to retailers about types of visual merchandising which can impress consumers' impulse buying behaviors. Although Previous studies indicated that window display did not appear to significantly lead to consumer impulse buying behavior ${ }^{5}$,the present study proved that window display can provoke impulse buying behavior in Iranian young adult female which emphasize in different geographic areas there are different ways to stimulate consumer's impulse buying behavior. Even though this study proved that cross merchandising did not appear to significantly cause to consumer's impulse buying behavior, this variable and impulse buying behavior are correlated which informs retailer managers to be cognizant of this factor. Impulse buying is more frequent in younger people versus older people ${ }^{18}$, this tenet might be important for shop manager to be aware of young people's needs which can boost their profits.

\section{References}

1. Dawson S, Kim M. External and internal trigger cues of impulse buying online. Direct Marketing: An International Journal. 2009; 3(1):20-34.

2. Miremadi A, Khoei R. The art of visual merchandising on consumer buying behavior. Int J Contemp Bus Stud. 2013; $4(6): 34-50$.

3. Soltani AR. Survey on shopping decision making styles on generation y consumer based on CSI model. [Master's Thesis]. Unpublished; 2008.

4. Janani M. Effect of merchandising activity on consumer purchase behavior: case study in Shirin Asal Co. [Master's Thesis]. Tehran: Alzahra University; Unpublished 2006.

5. Kim J. College student's apparel impulse buying behavior in relation to visual merchandising. [Master's Thesis]. Athens: University of Georgia; Unpublished; 2003.

6. Hoyer WD, Maclnnis DJ, Pieters R. Consumer Behavior. 6th ed. South-Western: Cengage Learning; 2013.

7. Yakup D, Mücahit C, Reyhan O. The impact of cultural factors on the consumer buying behaviors examined through an impirical study. Int J Bus Soc Sci. 2011; 2(5):109-14.

8. Karbasivar A, Yarahmadi H.Evaluating effective factors on consumer impulse buying behavior. Asian Journal of Business Management Studies. 2011; 2(4):174-81.

9. Cheng YH, Chuang SC, Wang SM, Kuo SY. The effect of companion's gender on impulsive purchasing: the moderating factor of cohesiveness and susceptibility to interpersonal influence. J Appl Soc Psychol. 2013; 43:227-36.

10. Park JE, Choi EJ. Consequences of impulse buying crossculturally: a qualitative study. International Int J Eng Res Appl. 2013; 7(1):240-60. 
11. Tendai M, Crispen C. In-store shopping environment and impulse buying. Afr J Market Manag. 2009; 1(4):102-08.

12. Muruganantham $G$, Bhakat RS. A review of impulse buying behavior. Int J Market Stud. 2013; 5(3):149-60.

13. Foroughi A, Buang NA, Senik ZC, Hajmisadeghi RS. Impulse buying behavior and moderating role of gender among Iranian shoppers. Journal of Basic and Applied Scientific Research. 2013; 3(4):760-69.

14. Peglar MM. Visual Merchandising and Display. 6th ed. Chapter one; Fairchild Books (A division of Conde Nast publication); 2011.
15. Leicham S. The woman friendly store. Conde Nast Sports; 2004. Available from: www.outdoorindustry.org

16. Schroeder LD, Sjoquist DL, Stephan PE. Understanding Regression Analysis. Sage Publication; 1986.

17. Mattila AS, Wirtz J. The role of store environment stimulation and social factors on impulse purchasing. J Serv Market. 2008; 22(7); 562-67.

18. Siddiqui K, Ahmed R. Impulse buying behavior among young children. Asian Journal of Research in Marketing. 2013; 2(4):25-32. 